\title{
THE IMPACT OF THE COVID-19 PANDEMICS OVER THE FINANCIAL PERFORMANCE AT THE LEVEL OF THE MAIN PHARMACEUTICAL OPERATING IN CENTRAL AND EASTERN EUROPE
}

\author{
Laurentiu DROJ', Goran KARANOVIC ${ }^{2}$, loan Gheorghe TARA ${ }^{1}$ \\ 'University of Oradea, Faculty of Economics, Finance and Accounting \\ Department, Oradea, Romania \\ 2University of Rijeka, Faculty of Tourism and Hospitality Management, Department \\ of Finance, Rijeka, Croatia \\ Laurentiu.droj@uoradea.ro \\ gorank@fthm.hr \\ itara@uoradea.ro
}

Abstract: The COVID19 pandemic seems to have affected the financial results of the companies operating in Central and Eastern Europe. This paper has as a main goal to analyse the impact of COVID-19 crisis over companies which operate in the pharmaceutical sector. Since two of the authors developed an article in 2018 concentrated on the Early warning indicators and their impact over the medical companies registered in the Bucharest Stock Exchange, the current article analysis the same indicators but extends them at the level of four countries: Romania, Croatia, Slovenia and Hungary. Within the paper the authors will compare the evolution of several financial indicators: liquidity, financial leverage, solvency, annual return, ROE, ROA, so on in context of COVID-19. The main reason for the selection of medical and pharmaceutical sector is constituted by the discussions that these companies benefit from the effects of COVID19.

Keywords: financial analysis, financial indicators, ROE, liquidity, solvency, COVID19, pharmaceutical sector

JEL classification: G34, G11, G32, O16, C58

\section{Introduction}

A large part of the media and also a large part of population consider that the impact of COVID-19 pandemics over the pharmaceutical sector has been a positive one by driving an increase in the consumption of medical equipment, prescription medicine and especially vaccines and therefore the financial results for these companies should be increasing in 2020. Opinions from other specialists are highlighting the fact that most of the investments, M\&A deals and sale were concentrated on COVID-19 products (Robke et all, 2020 and Rickwood \& Harb, 2020, BRK, 2021). 
The study published by BRK (2021) highlighted the fact that Sales of some product categories increased in 2020, such as medicines promoted as protection against COVID-19, those useful in relieving the symptoms of the virus (some painkillers, vitamins and food supplements that stimulate immunity) and those for sleep. This is due to the fact that as the news of the virus spread, consumers began to stock up on medicines that were considered essential.

The same study by BRK(2021) citing a study by Padmanabhan (2020) and published in Euromonitor: https://www.euromonitor.com/article/coronavirus-acceleratesdemand-for-immunity-and-holistic-wellness signals the fact that clients changed their behaviour and are concentrating over Immunity and holistic wellness decreasing the purchases for other type of pharmaceutical products such as weight management and wellbeing.

Figure 1 Consumer health by category

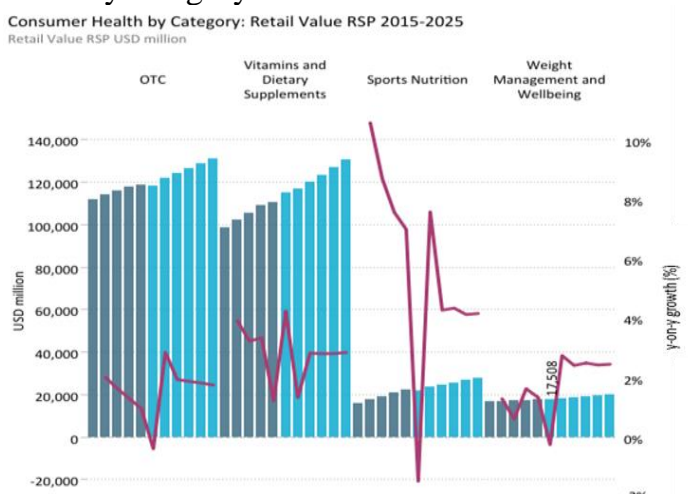

Source Padmanabhan (2020) in Euromonitor

https://www.euromonitor.com/article/coronavirus-accelerates-demand-for-immunity-andholistic-wellness

Since this article follows and can be considered as an extension of an article published by two of the authors Droj and Tara (2018) which is entitled Early warning indicators - evolution for the medical companies registered at BSE and which was published in the same Journal. The previous article intended to identify several early warning bankruptcy indicators and dealt with analyzing several models such as:

- Simple bankruptcy analysis pioneered by Beaver(1966) based on statistical methods

- Z-score model proposed by Altman (1968) a very popular model until now

- Multiple logistic regression models as proposed by Ohlson(1980)

- Neural networks championed by Charitou, Neophytou and Charalambous (2004)

- Econometric/Combined models (Tarnoczi and Fenyves, 2011, Bedenik et al., 2012)

Other complementary studies (Karanovic et all, 2018) are tackling issues such bankruptcy, insolvency or excessive debt at the level of companies and also increase of competitiveness and increase in revenues of the companies. 
In the following chapters the authors will present several financial indicators through which can be assessed the effects of COVID-19 pandemics over the pharmaceutical sector from Romania, Croatia, Hungary and Slovenia. These are indicators including both classical liquidity or solvency indicators (Droj, 2012) and financial or economic efficiency indicators (Droj, 2015).

\section{Selection of the financial indicators suitable for analyzing the impact of COVID 19 pandemics over the pharmaceutical sector}

The financial indicators which will be used to test the companies registered at the Romanian stock market were presented earlier by the author in other studies (Droj and Tara 2018). Several other authors dealt with analysis of financial indicators in the region: Rozsa (2014), Fenyves et all (2018) or Karanovic and Karanovic (2016)

As mentioned earlier the indicators selected are representative for the issues of financial efficiency, liquidity and solvency were selected the following indicators:

\section{Liquidity indicator:}

Current ratio (WCR) is used to analyse the ability of a company to pay its current liabilities its current assets. This ratio is also known as the working capital ratio.

$$
\text { WCR }=\frac{\text { Current assets }}{\text { Current Liabilities }}
$$

\section{Solvency ratio}

- shows the extent to which total debts are covered by total assets, and reflects the security enjoyed by creditors, as well as the creditworthiness of the company(Droj, 2012).

$$
\mathrm{Sv}=\frac{\text { Total assets }}{\text { Totaldebts }} \times 100
$$

\section{Return Indicators as presented by Droj (2015) and Rozsa (2012):}

- The Return on Equity (ROE), also known in French economic literature as "financial return rate", and abbreviated in the specialized literature as ROE. This indicator shows the efficiency of the capital invested by shareholders. ROE constitutes one of the most important return indicators, being used by company owners and potential investors in the investment decision-making process.

$$
\mathrm{ROE}=\frac{\text { Net } \text { Profit }}{\text { Equity }}
$$

These indicators were tested by using financial data for companies operating in Tourism industry in Romania, Croatia, Hungary and Slovenia accessed from 
Amadeus databases (https://amadeus.bvdinfo.com/). The collected information is analyzing the Financial Reports of the selected companies in the period 20162020.

\section{Assessing the impact of COVID 19 pandemics over the pharmaceutical sector from central and Eastern Europe in the period 2016-2020}

After a period (2016-2019) of consolidation and fierce competition in the pharmaceutical sector, the COVID-19 pandemics brought new challenges and opportunities for the pharmaceutical sector. The companies selected for the study are having the following key financial information: turnover over 5 million EURO and bellow 50 million EURO.

The selection used a Boolean algorithm in order to select the most representative pharmaceutical companies from Romania, Croatia, Hungary and Slovenia. The first step of analyzing the impact of COVID 19 over these companies was analyzing the evolution in the period 2016-2020 of the turnover, cash flow and number of employees.

As can be seen from the analysis of the Return on Equity this indicator managed to improve significantly in the COVID-19 pandemics from a median of $11 \%$ and an average of $10 \%$ this indicator achieved an average a median of $16 \%$, even if the results in Slovenia were negative.

Table 1 Evolution of Return on Assets (ROA) - 2016-2020

\begin{tabular}{|l|c|c|c|c|c|}
\hline ROE \% & $\mathbf{2 0 1 6}$ & $\mathbf{2 0 1 7}$ & $\mathbf{2 0 1 8}$ & $\mathbf{2 0 1 9}$ & $\mathbf{2 0 2 0}$ \\
\hline Slovenia & 18 & 9 & 14 & -4 & -13 \\
\hline Romania & 24 & 17 & 16 & 15 & 15 \\
\hline Hungary & 13 & 14 & 12 & 8 & 16 \\
\hline Croatia & -5 & 5 & 7 & 20 & 25 \\
\hline TOTAL & $\mathbf{1 5}$ & $\mathbf{1 2}$ & $\mathbf{1 1}$ & $\mathbf{1 1}$ & $\mathbf{1 6}$ \\
\hline Median & $\mathbf{1 5}$ & $\mathbf{1 2}$ & $\mathbf{1 3}$ & $\mathbf{1 2}$ & $\mathbf{1 6}$ \\
\hline Average & $\mathbf{1 2}$ & $\mathbf{1 1}$ & $\mathbf{1 2}$ & $\mathbf{1 0}$ & $\mathbf{1 1}$ \\
\hline
\end{tabular}

Source: Calculation of the authors based on the data from www.bvb.ro

The biggest improvement for this indicator was registered by companies from Hungary and Croatia, while the selected companies from Romania maintained the same level.

Figure 2 Evolution of Return on Assets (ROA) - 2016-2020 


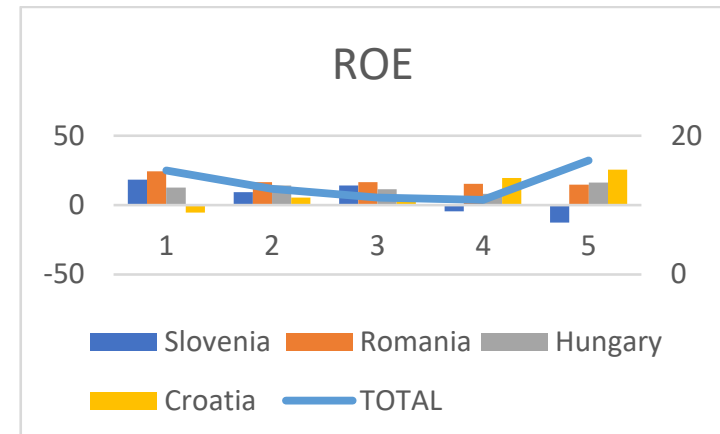

Source: Calculation of the authors based on the data from https://amadeus.bvdinfo.com/).

In which concerns the liquidity indicator we can see that the overall evolution is extremely positive both at the level on the entire sector and at the level of individual country. Even the companies from Slovenia improved their values from the all time low of 2018.

Table 2 Evolution of Liquidity ratio - 2016-2020

\begin{tabular}{|c|l|l|l|l|l|}
\hline Liquidity ratio & $\mathbf{2 0 1 6}$ & $\mathbf{2 0 1 7}$ & $\mathbf{2 0 1 8}$ & $\mathbf{2 0 1 9}$ & $\mathbf{2 0 2 0}$ \\
\hline TOTAL & $\mathbf{2 . 3 3}$ & $\mathbf{2 . 3 5}$ & $\mathbf{2 . 2 1}$ & $\mathbf{2 . 5 6}$ & $\mathbf{2 . 6 4}$ \\
\hline Slovenia & 1.39 & 0.98 & 0.51 & 0.63 & 0.85 \\
\hline Romania & 2.15 & 2.20 & 2.26 & 2.46 & 2.47 \\
\hline Hungary & 2.53 & 2.63 & 1.89 & 3.03 & 3.20 \\
\hline Croatia & 2.12 & 2.29 & 3.00 & 2.19 & 2.32 \\
\hline Median & $\mathbf{2 . 1 3}$ & $\mathbf{2 . 2 5}$ & $\mathbf{2 . 0 7}$ & $\mathbf{2 . 3 2}$ & $\mathbf{2 . 4 0}$ \\
\hline Average & $\mathbf{2 . 0 5}$ & $\mathbf{2 . 0 3}$ & $\mathbf{1 . 9 1}$ & $\mathbf{2 . 0 8}$ & $\mathbf{2 . 2 1}$ \\
\hline
\end{tabular}

Source: Calculation of the authors based on the data from https://amadeus.bvdinfo.com/).

The liquidity indicator shows and extremely healthy sector in Hungary (3.20), Romania (2.47) and Croatia (2.32), in all these countries the values increased comparing with 2019 and in Hungary and Romania these values are at the all-time high. 
Figure 3 Evolution of Liquidity ratio - 2016-2020

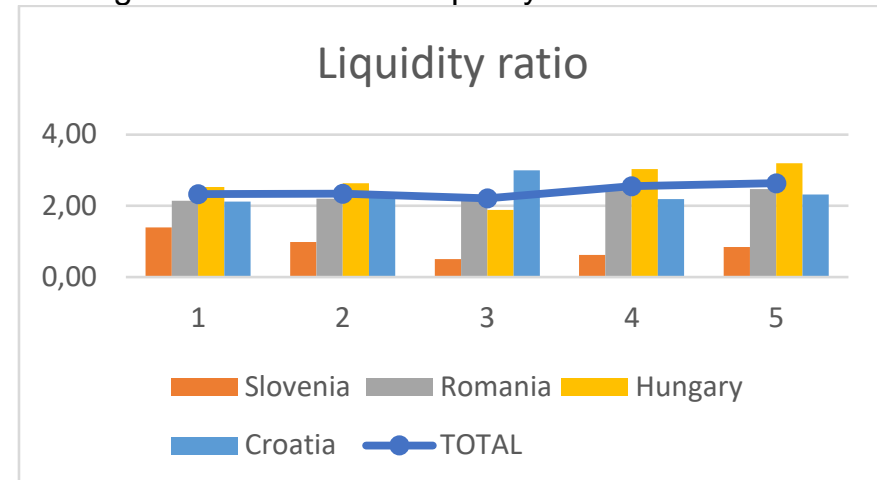

Source: Calculation of the authors based on the data from https://amadeus.bvdinfo.com/).

The solvency follows the evolution of the liquidity indicator, where the results are having an extremely positive tendency in 2020 improving significantly from 2019. The lowest levels for this indicator are registered at the level of the Slovenian companies included in the study $27.95 \%$ in 2020 , increasing from $18.78 \%$ in 2019

Table 3 Evolution of Solvency Ratio - 2016-2020

\begin{tabular}{|c|c|c|c|c|c|}
\hline $\begin{array}{c}\text { Solvency ratio } \\
\text { (Liability based) \% }\end{array}$ & $\mathbf{2 0 1 6}$ & $\mathbf{2 0 1 7}$ & $\mathbf{2 0 1 8}$ & $\mathbf{2 0 1 9}$ & $\mathbf{2 0 2 0}$ \\
\hline TOTAL & $\mathbf{4 3 . 6 0}$ & $\mathbf{5 5 . 7 8}$ & $\mathbf{4 8 . 3 2}$ & $\mathbf{5 0 . 6 1}$ & $\mathbf{5 8 . 9 5}$ \\
\hline Slovenia & 38.98 & 47.86 & 31.45 & 18.78 & 27.95 \\
\hline Romania & 34.68 & 48.74 & 48.42 & 48.05 & 53.99 \\
\hline Hungary & 49.44 & 63.17 & 48.66 & 59.40 & 60.47 \\
\hline Croatia & 61.66 & 58.85 & 61.99 & 55.32 & 67.70 \\
\hline Median & $\mathbf{4 4 . 2 1}$ & $\mathbf{5 3 . 8 0}$ & $\mathbf{4 8 . 5 4}$ & $\mathbf{5 1 . 6 9}$ & $\mathbf{5 7 . 2 3}$ \\
\hline Average & $\mathbf{4 6 . 1 9}$ & $\mathbf{5 4 . 6 6}$ & $\mathbf{4 7 . 6 3}$ & $\mathbf{4 5 . 3 9}$ & $\mathbf{5 2 . 5 3}$ \\
\hline
\end{tabular}

Source: Calculation of the authors based on the data from https://amadeus.bvdinfo.com/).

The biggest achievers are the companies from Croatia which increased their financial stability from $55.32 \%$ in 2019 to $67.70 \%$ solvency in 2020 . Positive evolutions were recorded at the level of Romanian (53.99\%) and Hungarian (60.47\%) companies. 
Figure 3 Evolution of Solvency ratio - 2016-2020

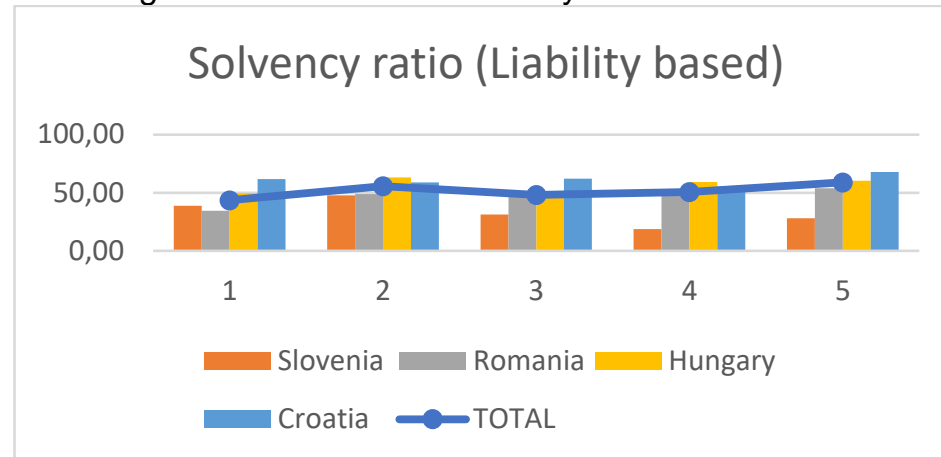

Source: Calculation of the authors based on the data from https://amadeus.bvdinfo.com/).

\section{Conclusions}

After the analysis of the data, it is clear that the financial results of the pharmaceutical companies improved consistently in 2020, the first year where the COVID-19 effects were felt by the pharmaceutical sector. It is clear that the pharmaceutical sector reacted properly to the increasing demand in medicines promoted as protection against COVID-19, those useful in relieving the symptoms of the virus (some painkillers, vitamins and food supplements that stimulate immunity) and those for sleep. A clear view over the positive impact over the financial results, caused in this sector by COVID-19 pandemics, can be realized only after the analysis of the financial information for 2021 and the years postCovid.

As a general conclusion of this paper, we can consider that the indicators used in this study should be accompanied by several other types of indicators both financial, macro-economic, sectorial and also non-financial qualitative or quantitative. This study should be continued on a larger scale and including other indicators in order to establish which elements should be tackled first when dealing with the effects of COVID-19 crisis over the pharmaceutical sector.

\section{References}

1. Altmacharitn, E. I. (1968), "Financial ratios, discriminant analysis and the prediction of corporate bankruptcy", The Journal of Finance, Vol. 23, No. 4, pp. 589-609.

2. Altman, E. I. (1993). Corporate financial distress and bankruptcy. New York: NY, John Wiley and Sons, In.

3. Amadeus, 2021, Amadeus Database - Software version 16.12 - data update 22.11.2021 https://amadeus.bvdinfo.com/ accessed in 26.11.2021

4. Beaver, W. H. (1966), "Financial ratios as predictors of failure", Journal of Accounting Research, Vol. 4, pp. 71-111.

5. Bedenik, N. O., Rausch, Al., Fafaliou, Ir., \& Labaš, D. (2012). Early Warning System - Empirical Evidence. In: TRŽIŠTE, 24 (2), 201-218.

6. Charitou, A., Neophytou, E., and Charalambous, C. (2004). Predicting corporate failure: Empirical evidence for the UK. European Accounting Review 13(3), 465497. 
7. BRK Financial Group, 2021, Raport de Analiza Biofarm, https://www.brk.ro/cotatiisi-analize/rapoarte-de-analiza/raport-de-analiza-biofarm/

8. Droj, L., 2012 Financial Performance Analysis based on the Financial Statements for the Companies Located in the Bihor - Hajdu Bihar Euroregion, Published in Annals of the University of Oradea, Economic Science Series;2012, Vol. 21 Issue 2, p464, Oradea, Romania http://connection.ebscohost.com/c/articles/85948972/financial-performanceanalysis-based-financial-statements-companies-located-bihor-hajdu-bihareuroregion

9. Droj, L. 2015 Study Regarding the Profitability Indicators for the Romanian Companies Operating in the Tourism and Leisure Services Sector in the Period of 2010-2013 available online http://steconomiceuoradea.ro/anale/volume/2015/n1/093.pdf

10. Droj L., Tara I.G., 2018, Early warning indicators - evolution for the medical companies registered at BSE, available online https://ideas.repec.org/a/ora/journl/v1y2018i2p102-108.html

11. Fenyves, Veronika \& Bács, Zoltán \& Zéman, Zoltán \& Böcskei, Elvira \& Tarnoczi, Tibor. (2018). The role of the notes to the financial statements in corporate decision-making. Corporate Ownership \& Control. 15. 138-148. $10.22495 / \operatorname{cocv} 15 i 4 \mathrm{c} 1 \mathrm{p} 1$.

12. Goran Karanovic, Bisera Karanovic, and Martina Gnjidic. 2018. Liquidity Risk Management: Practice Among Croatian Firms. Journal of the Polytechnic of Rijeka, 6(1), 81-98.

13. Karanovic, Goran, and Bisera Karanovic. 2016. IPOs Performance Analysis: Evidence from Emerging Markets in the Balkans. Scientific Annals of Economics and Business 63(3): 381-389. DOI: 10.1515/saeb-2016-0129

14. Ohlson, J. A. (1980). Financial ratios and the probabilistic prediction of bankruptcy. Journal of Accounting Research 18(1), 109-131.

15. Padmanabhan J. (2020) Coronavirus Accelerates Demand for Immunity and Holistic Wellness published in Euromonitor 2020, https://www.euromonitor.com/article/coronavirus-accelerates-demand-forimmunity-and-holistic-wellness

16. Rickwood, S; Harb, N. 2020, Taking stock: An assessment of 2020 for the EU5 pharma market, and the lessons for 2021, webinar Webinar: September 29, 2020, IQWIA available online: https://www.iqvia.com/library/white-papers/monitoring-theimpact-of-covid-19-on-the-pharmaceutical-market-eu5

17. Robke, L; Berghauser Pont, L.; Bongard, J., Wurzer, S; Smietana, K and Moss, R 2020, Impact of COVID-19 on pharmaceutical external innovation sourcing, published in Nature Reviews Drug Discovery 19, 829 (2020)

18. Rozsa, A. (2014), Financial position of building industry in Hajdú-Bihar county ( $E$ Hungary) in the period of 2008-2012: Regional sectoral analysis based on economic performance ratios, published in International Review Of Applied $\begin{array}{llll}\text { Sciences And } \quad \text { Engineering } & \text { 67-77, }\end{array}$ http://www.akademiai.com/doi/abs/10.1556/IRASE.5.2014.1.9

19. Tarnoczi, Tibor \& Fenyves, Veronika. (2011). LIQUIDITY MANAGEMENT AND CORPORATE RISK. Annals of Faculty of Economics. 1. 530-536. 